\title{
IMPLEMENTASI PEMBELAJARAN LANGSUNG MEMBUAT PAES PROPOSIONAL PADA PENGANTIN INDONESIA JOGJA
}

\author{
${ }^{1}$ Vony F.S Hartini Hippj, ${ }^{2}$ Sulistiami \\ ${ }^{1}$ Fakultas Keguruan dan Ilmu Pendidikan, Universitas Adibuana Surabaya \\ email: vonnyhippy@yahoo.com \\ ${ }^{2}$ Fakultas Keguruan dan Ilmu Pendidikan, Universitas Adibuana Surabaya \\ email: sul_is@yahoo.co.id
}

\begin{abstract}
Study aims to determine the results of learning to make paes proportionally through direct learning model approach. The study used a one shots case study design study. The subjects of the study were students of Adi Buana University class of 2016, amounting to 25 people. Methods of data collection using written tests make design and performance tests make paes on the model. The bride Yogja Putri is one of the bridal makeup styles of court the Yogjakarta. Characteristic of the bride Java princess is a form of paes on the forehead that only uses a shoot, without using prada. Making bridal paes both solo and Yogja, Originally using traditional methods, but as the development of science then the method proportional to alternative making paes. Paes is a black or green forehead makeup. Paes on the bride Yogja consists of 4 parts, namely penunggul, penyep, penitis and godeg. The purpose of this study is to know the learning outcomes of making Yogja princess paes with direct learning model proportionally, Proportional Technique is Technique of making paes which base on visualization of bridal face that is peak of nose and corner of eye of outside. These benchmarks are used to make penunggul, penitis, pengapit and godeg. The purpose of making paes proportionally is to ease in making paes for beginners, especially students. Learning outcomes make paes proportionally easier by using visualization of the bridal face as a benchmark. This is evidenced by the increase of learning outcomes from making the design to the actual model of the cycle I average obtained by $83.3 \%$, the second cycle of $89.7 \%$, and the average III cycle obtained $95.5 \%$.
\end{abstract}

Keywords: Direct Learning, Jogja Putri Bride, Propositional Method.

\section{PENDAHULUAN}

Pendidikan sangat trategis dalam mencerdaskan kehidupan bangsa yang diperlukan untuk meningkatkan mutu bangsa secara menyeluruh di Indonesia. Indonesia terkenal dengan keanekaragaman suku dan budaya. Satu diantara keanekaragaman tersebut nampak pada tata rias pengantin. Setiap daerah memiliki tata rias pengantin yang berbeda-beda, mulai dari rias wajah, penataan rambut dan tata busananya. Perbedaan tersebut dipengaruhi oleh banyaknya kebudayaan yang masuk ke Indonesia saat itu. Pulau jawa memiliki beberapa jenis pengantin dengan berbagai macam penataan, mulai dari jawa tengah, jawa barat, jawa timur, dan DKI Jakarta. Bentuk penataan pengantin untuk daerah jawa tengah dibedakan menjadi dua daerah, yakni solo dan jogja.

Tata rias pengantin yang paling banyak diminat konsumen saat ini adalah tata rias pengantin jogja, baik jogja putri maupun jogja paes ageng. Untuk tata rias pengantin jogja putri biasanya digunakan ketikan konsumen melakukan akad nikah. Persamaan tata rias pengantin jogja putri dan jugja paes ageng adalah sama-sama menggunakan riasan pada dahi. Riasan hitam pada dahi tersebut adalah paes yang digunakan dahi pengantin solo dan jogja. Paes tidak hanya digunakan pada pengantin jawa saja, tetapi beberapa pengantin 
dari luar jawa juga banyak yang menggunakan paes, hanya saja masing-masing daerah berbeda dalam nama dan istilah.

Paes pada tata rias pengantin jogja putri berwarna hitam yang terdiri dari 4 bagian, yakni penunggul, penetep, penitis dan godeg. Dari keempat jenis tersebut memiliki bentuk yang berbeda. Dalam membuat bentuk-bentuk tersebut, perias memiliki teknik dan cara yang berbeda-beda. Pembuatan paes umumnya masih tradisional yakni menggunakan perhitungan jari perias. Dari hitungan jari perias tersebut maka sering timbul masalah, yakni bentuk paes yang dihasilkan terlihat aneh diwajah pengantin. Hal ini disebabkan oleh besar kecilnya jari perias berbanding terbalik dengan besar kecilnya dahi pengantin.

Untuk mengakumulasi perbedaan tersebut maka dibutuhkan metode dalam membuat paes melalui penerapan model pembelajaran langsung. Pembelajaran langsung adalah salah satu pendekatan mengajar yang dirancang khusus untuk menunjang proses belajar yang berkaitan dengan pengetahuan deklaratif dan procedural yang terstruktur dengan baik yang dapat diajarkan selangkah demi selangkah. Landasan berfikir dari model pembelajaran langsung adalah teori pemodelan tingkah laku.

Berdasarkan permasalahan tersebut, maka penulis mencoba untuk mengimplementasikan pembelajaran langsung membuat paes dengan metode proposional yang menggunakan visualisasi dari wajah pengantin.

\section{KAJIAN LITERATUR DAN PENGEMBANGAN HIPOTESIS \\ Pembelajaran Langsung}

Pembelajaran langsung adalah suatu pendekatan mengajar yang dapat membantu siswa mempelajari keterampilan dasar dan memperoleh informasi yang dapat diajarkan selangkah demi selangkah (Kardi dan Nur, 2000:2). Menurut Arends (2007:29) pembelajaran langsung adalah salah satu pendekatan mengajar yang dirancang khusus untuk menunjang proses belajar siswa yang berkaitan dengan pengetahuan deklaratif dan pengetahuan prosedural yang trestruktur dengan baik yang dapat diajarkan dengan pola kegiatan bertahap, selangkah demi selangkah. Landasan berfikir untuk model pembelajaran langsung adalah teori pemodelan tingkah laku.

Ciri dari model pembelajaran langsung sebagai berikut: adanya tujuan pembelajaran dan pengaruh model pada peserta didik, pola keseluruhan dan alur pembelajaran, dan system pengelolaan lingkungan belajar diperlukan agar kegiatan pembelajaran tertentu dapat berlangsung dengan maksimal.

Tata rias pengantin jogja

Rias adalah tindakan mempercantik diri atau konsumen. Tata rias adalah suatu ilmu pengetahuan dan keterampilan yang dimiliki oleh penata rias. Tata rias pengantin adalah karya seni budaya bangsa yang berkembang dalam sebuah kelompok masyarakat untuk dilestarikan (Marmien, 2008:134).

Pembuatan paes dengan metode proposional adalah Teknik membuat paes yang menggunakan visualisasi dari wajah pengantin.

\section{HASIL DAN PEMBAHASAN}

Penelitian ini menggunakan rancangan penelitian one shot case study dengan menerapkan model pembelajaran langsung. Data diambil melalui 3 kali pembelajaran. Pembelajaran pada hari 1 membuat desain pada kertas, pembelajaran dilakukan dengan baik meskipun banyak kekurangan. Kekurangan tersebut terletak pada keterampilan mahasiswa dalam membuat desain yang masih kurang. Pembelajaran hari 2, suasana kelah lebih tenang, mahasiswa lebih semangat praktek langsung menggunakan model daripada menggambar pada kertas. Pembelajaran hari ke 3, mahasiswa langsung praktek dengan model. Dari hasil pembelajaran dihari 1 dan hari 2 memiliki dampak yang cukup baik.

Berikut hasil belajar peserta didik selama penelitian berlangsung. 


\begin{tabular}{|l|l|l|l|l|}
\hline No & Nama siswa & $\mathrm{H} 1$ & $\mathrm{H} 2$ & $\mathrm{H} 3$ \\
\hline 1. & Aci savita & 75 & 87 & 90 \\
\hline 2. & Aprilia aaries tanti & 70 & 80 & 89 \\
\hline 3. & Dana iswara & 75 & 85 & 85 \\
\hline 4. & $\begin{array}{l}\text { Devi duwita } \\
\text { purindah }\end{array}$ & 85 & 80 & 85 \\
\hline 5. & Devi irma cahyani & 75 & 79 & 85 \\
\hline 6. & Dinda afria & 85 & 80 & 85 \\
\hline 7. & Dwi ainun fitria & 75 & 85 & 89 \\
\hline 8. & Dwi pertiwi oktafia & 80 & 80 & 80 \\
\hline 9. & Efi rahmawati & 81 & 80 & 85 \\
\hline 10. & Eka dian pertiwi & 75 & 85 & 91 \\
\hline 11. & Evi susanti & 85 & 85 & 85 \\
\hline 12. & Fine erliana & 75 & 85 & 89 \\
\hline 13. & Fitria ainun zilvi & 70 & 70 & 70 \\
\hline 14. & Iga mey margasari & 75 & 79 & 85 \\
\hline 15. & Lailatul chotimah & 85 & 80 & 85 \\
\hline 16. & Lina dwi arini & 75 & 85 & 91 \\
\hline 17. & Novia savitri & 80 & 84 & 85 \\
\hline 18. & Nurul kharisma & 75 & 85 & 89 \\
\hline 19. & Oktavia dwiningsih & 85 & 85 & 85 \\
\hline 20. & $\begin{array}{l}\text { Riska ridho } \\
\text { febrianti }\end{array}$ & 81 & 80 & 85 \\
\hline 21. & Restu indra lestari & 85 & 80 & 85 \\
\hline 22. & $\begin{array}{l}\text { Setiyo windi meita } \\
\text { sari }\end{array}$ & 75 & 85 & 89 \\
\hline 23. & Sulastri puji astutik & 85 & 75 & 75 \\
\hline 24. & Susianti & 80 & 75 & 80 \\
\hline 25. & Yanti pertiwi & 90 & 85 & 89 \\
\hline & & & & \\
\hline
\end{tabular}

Rata-rata diperoleh presentase Menggambar desain

\begin{tabular}{|c|c|c|}
\hline $\begin{array}{c}\text { Sko } \\
\mathbf{r}\end{array}$ & Hasil & Kategori \\
\hline 1 & $0 \%$ & - \\
\hline 2 & $0 \%$ & - \\
\hline 3 & $48 \%$ & Cukup Baik \\
\hline 4 & $80 \%$ & Baik \\
\hline
\end{tabular}

Model

\begin{tabular}{|c|c|c|}
\hline Skor & Hasil & Kategori \\
\hline 1 & $0 \%$ & - \\
\hline 2 & $83,3 \%$, & Cukup Baik \\
\hline 3 & $89,7 \%$, & Baik \\
\hline 4 & $95,5 \%$ & Sangat \\
& \multicolumn{2}{|c|}{ Baik } \\
\hline
\end{tabular}

\section{KESIMPULAN}

Penerapan model pembelajaran langsung dapat meningkatkan hasil belajar peserta didik, hal ini dapat dilihat dari hasil belajar hari 1, hari 2, dan hari 3. Hampir semua peserta didik mendapatkan nilai yang sempurna.

Berdasarkan pengalaman, teknik pembuatan paes secara tradisional memiliki kekurangan bagi pemula, yakni kesulitan menentukan posisi jari dengan dahi model, hasil paes terlihat aneh pada dahi model. Solusi yang dapat diberikan bagi perias pemula adalah menggunakan metode pembuatan paes secara proposional. Teknik proposional adalah Teknik dalam membuat paes yang menggunakan visualisasi dari wajah model.

Dilihat dari hasil secara individu, maka diharapkan pengajar dapat menerapkan model pembelajarn ini pada materi lain dan dikembangkan menjadi lebih baik.

\section{REFERENSI}

A.A. Djamadil. 1990. Mengenal Kebudayaan

Daerah Indonesia. Jakarta. Prakarsa Mampang Sejahtera

Andiyanto. 2004. The Make Over Rahasia Rias

Wajah. Jakarta. Gramedia.

Depdikbud. 1987. Arti Lambang dan Fungsi

Tata Rias Pengantin dalam

Menanamkan Nilai-Nilai Budaya.

Yogyakarta. Depdikbud. Maudy. Hand

Out. 2012. Tidak diterbitkan. Naniek

Saryoto.1995. Pelajara Tata Rias

Pengantin Basahan Surakarta. PT.

Carina Indah Utama, Jakarta.

Puspita Martha. 2010. Pengantin Solo Putri \&

Basahan Prosesi, Tata Rias \& Busana.

Jakarta: PT Gramedia Pustaka Utama. 